Bull. Chem. Soc. Ethiop. 2016, 30(1), 39-54.

Printed in Ethiopia

ISSN 1011-3924

DOI: http://dx.doi.org/10.4314/bcse.v30i1.4

(C) 2016 Chemical Society of Ethiopia

\title{
COMPARISON OF SIMPLE AND CHELATED AMBERLITE IR-120 FOR PRECONCENTRATION AND DETERMINATION OF Cu(II) FROM AQUEOUS SAMPLES
}

\author{
Maria Sadia ${ }^{1,2^{*}}$, Mohammad Rasul $\mathrm{Jan}^{2}$, Jasmin Shah ${ }^{2}$ and Atta-ul-Haq ${ }^{3}$ \\ ${ }^{1}$ Department of Chemistry, University of Malakand, K. P. K., Pakistan \\ ${ }^{2}$ Institute of Chemical Sciences, University of Peshawar, K.P.K., Pakistan \\ ${ }^{3}$ Department of Chemistry, GC University, Faisalabad, Pakistan
}

(Received September 21, 2014; revised September 17, 2015)

\begin{abstract}
In the present study, the efficiency of simple and chelating Amberlite IR-120 with $\alpha$-nitroso $\beta$ naphthol (IR- $\alpha \mathrm{N} \beta \mathrm{N}$ ) and with 8-hydroxy quinoline (IR-8HQ) has been compared for the removal of $\mathrm{Cu}(\mathrm{II})$ from aqueous solutions. The chelation was confirmed using different characterization techniques like SEM, TGA and FTIR. A number of experiments were carried out in batch system to determine the effect of different parameters on adsorption of $\mathrm{Cu}$ (II) like $\mathrm{pH}$, contact time and sample volume. The results showed occurrence of maximum adsorption at pH 7 in 10 min with adsorption capacity of $71.5 \mathrm{mg} \mathrm{g}^{-1}$ at $298 \mathrm{~K}$. The adsorption followed pseudo second order kinetic model among the four kinetic models applied. Maximum desorption from IR-8HQ was obtained with a mixture of $4.0 \mathrm{M} \mathrm{HCl}$ and $0.5 \mathrm{M} \mathrm{HNO}_{3}$. Furthermore, IR-8HQ was found to be most selective adsorbent among three adsorbents investigated. The developed preconcentration procedure was successfully applied to spiked tap water and real samples.
\end{abstract}

KEY WORDS: Chelating adsorbent, Amberlite IR-120, $\alpha$-Nitroso $\beta$-naphthol, 8-Hydrox quinoline, Preconcentration

\section{INTRODUCTION}

With the rapid development of industries, the environmental pollution along with the water pollution containing many toxic metals is important research focuses in terms of natural equilibrium and health of all organisms. To improve the quality and quantity, it is important to monitor the amount of trace metal ions in the samples of environmental importance and it has become a more demanding issue. Industries that introduce trace metals in the environment are predominantly metal sanitizing, paints and tinctures, metal extraction, batteries discharge and industrial effluents [1-3]. Copper is one of the heavy metals that tends to accumulate in the body and causes mucosal irritation, lung cancer, damage to capillary, kidney and liver and gastrointestinal symptoms such as diarrhea, abdominal pain, nausea, and vomiting [4]. Sources of copper in drinking water are mining, ores processes and from industries like chemical, fertilizer, textile dyeing, printing, and paper and pulp mills [5]. This makes the elimination of copper very important not only due its adverse effects on human health but also the probability of its reuse in many industries [6].

Different preconcentration procedures have been broadly used for removal of heavy metals and these include liquid-liquid or ion exchange extraction, coprecipitation, membrane separation and bio or chemical adsorption. Chelating ion exchange adsorption is one of the most nominal preconcentration methods due to its good mechanical stability, selectivity from a large aqueous volume, high enrichment factor, higher degree of interaction between adsorbate and adsorbent, high adsorption capacity for metal ions and regeneration of chelated resins. Therefore the demand of these chelated polymer resins for trace metal determination is increasing day by day. This is because; chelated polymer resins can be used for trace metal investigation mainly for water, biological and geological samples [7].

*Corresponding author. E-mail: mariasadia@gmail.com 
Different chelated polymer resins have been used for preconcentration of trace metals. Among these the most widely used are chelated Amberlite XAD-2 [8], XAD-7 [9], XAD-16 [10], XAD-2000 [11] and in addition activated alumina [12], and activated carbon [13] have also been used. Many chelating ligands such as quinolone, 2-amino-2-thiazoline, pyridine and aminophosphonate have been broadly used for chelating polymer resins [14].

The chelated polymer resins with higher adsorption capacities can be prepared by taking chelating ligand of small size with populated functional group bound to a suitably cross-linked polymer. Due to the presence of different donor atoms on chelating ligands like oxygen, sulphur, nitrogen, these chelating ligands become more selective for adsorption of specific metal ion. The most widely used methods applied for preparation of chelated resins are either by simple adsorption of ligand on the polymer resin or by the intermediate functional group such as $-\mathrm{N}=\mathrm{N}-$ by diazotization or $-\mathrm{CH}_{2}-$ by methylene chloride reaction. Chelating polymers synthesized by covalent bonds are much more resistant to external effects than those by simple adsorption [15].

Amberlite IR-120, a vinyl benzene polymer has good chemical, physical and thermal stability. It has high exchange capacity and good ion exchange kinetics. These specific characteristics make it a good resin for use as a solid support. In the present study Amberlite IR120 has been functionalized with $\alpha$-nitroso $\beta$-naphthol and 8-hydroxy quinoline for preconcentration and determination of $\mathrm{Cu}$ (II) from aqueous samples and the results have been compared with the simple Amberlite IR-120.

\section{EXPERIMENTAL}

\section{Instruments}

For characterization of the adsorbents used for preconcentration, scanning electron microscope model JEOL-JSM-5910 (Japan), Perkin Elmer Diamond TG/DTA and FTIR spectrophotometer Pretige 21 Shimadzu (Japan) were used. For the analysis of Cu(II) Perkin Elmer AAnalyst 200 (USA) atomic absorption spectrophotometer was used.

\section{Reagents and chemicals}

All chemicals and reagents used in this work were of analytical reagent grade purity and were manufactured by Merck, Germany. Chelating agent 8-hydroxy quinoline was obtained from Scharlau Chemie, USA, while Amberlite IR-120 was obtained from Across Organics, Belgium.

\section{Solution preparation}

Stock $1000 \mu \mathrm{gmL}^{-1}$ copper standard solution was purchased from Merck. Working standards were prepared from this solution by dilution. Britton Robinson buffer solutions of $\mathrm{pH} 2-8$ were prepared according to standard procedure [16] and were used for the adjustment of solution $\mathrm{pH}$.

Chelation of Amberlite IR-120

Chelation of Amberlite IR-120 was done according to the procedure given in literature [15] with little modifications. $20 \mathrm{~g}$ of Amberlite IR-120 (acid washed) was added to $80 \mathrm{~mL}$ mixture (3:5) of conc. nitric acid and sulphuric acid and was stirred for one $\mathrm{h}$ at $60{ }^{\circ} \mathrm{C}$. The mixture was then poured into ice cold water, filtered and washed with distilled water many times until it was free from acid. Nitration was achieved at this step. Nitro group on the polymer was then reduced to amino by refluxing it in the presence of stannous chloride $(40 \mathrm{~g})$, conc. hydrochloric acid (50 $\mathrm{mL})$ and distilled ethanol $(60 \mathrm{~mL})$ for $12 \mathrm{~h}$ at $70{ }^{\circ} \mathrm{C}$. The resultant amino polymer was treated with $100 \mathrm{~mL}$ of $2 \mathrm{M}$ hydrochloric acid for $30 \mathrm{~min}$ to remove stannous chloride and then washed with distilled water to remove excess of hydrochloric acid. The polymer was then suspended in $250 \mathrm{~mL}$ of an ice cold water and to this polymer was added $2 \mathrm{~mL}$ of $1 \mathrm{M}$ hydrochloric acid 
followed by the addition of $2 \mathrm{~mL}$ of $1 \mathrm{M}$ sodium nitrite with constant stirring for $30 \mathrm{~min}$ for diazotization. The diazotized resin was filtered, washed with ice cold water and was then coupled with $\alpha$-nitroso $\beta$-naphthol $(\alpha \mathrm{N} \beta \mathrm{N})$ by stirring it for 3 hours in $100 \mathrm{~mL}$ of $3 \% \alpha$-nitroso $\beta$ - naphthol solution prepared in distilled ethanol. After coupling the chelated resin was washed with ethanol to remove any unreacted $\alpha$-nitroso $\beta$-naphthol. Chelation with 8 -hydroxy quinolone (8HQ) was also done using the same procedure. The proposed reaction mechanism is given in Figure 1.

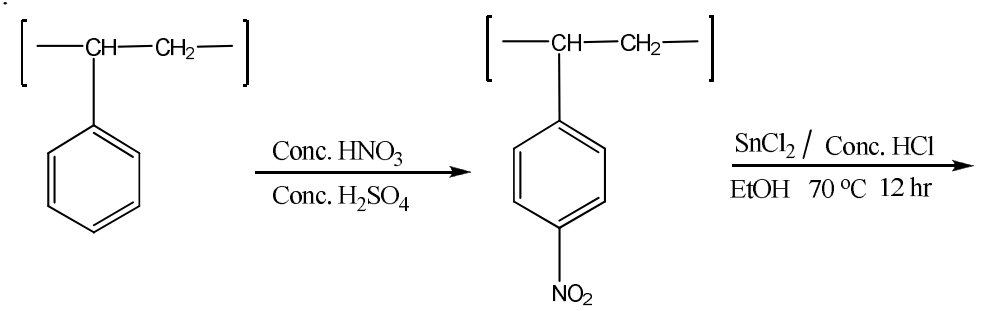

Nitropolymer
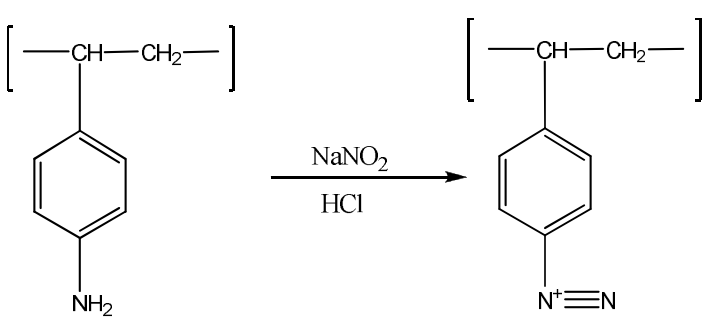

Aminopolymer<smiles>CCC(C)c1ccc(N=N)cc1</smiles>

$+$

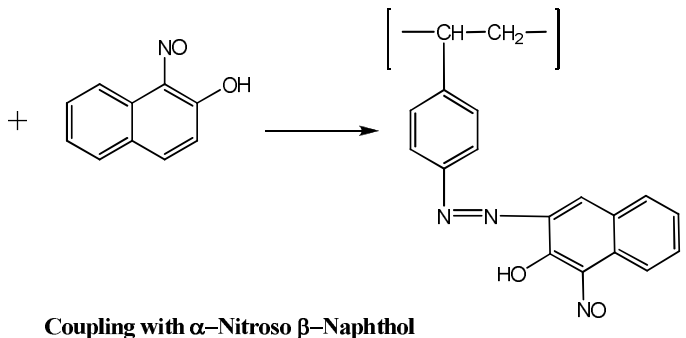

Coupling with $\alpha$-Nitroso $\beta$-Naphthol

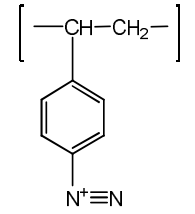<smiles>Oc1cccc2cccnc12</smiles>

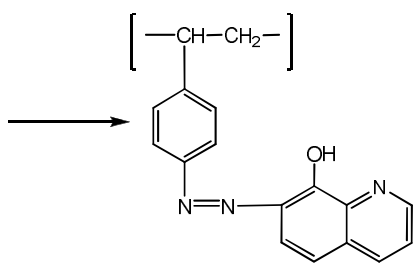

Coupling with 8-Hydroxy Quinoline

Figure 1. Proposed reaction mechanism for modification of Amberlite IR-120 with $\alpha \mathrm{N} \beta \mathrm{N}$ and $8 \mathrm{HQ}$. 
Batch adsorption experiments using simple and chelated resins

For the adsorption of $\mathrm{Cu}$ (II) from aqueous solutions, $100 \mathrm{mg}$ of simple and chelated resins were taken in separate beakers. To each beaker $50 \mathrm{~mL}$ of $10 \mu \mathrm{g} \mathrm{mL}^{-1}$ of $\mathrm{Cu}$ (II) solution was added. The $\mathrm{pH}$ of each solution was adjusted to the required $\mathrm{pH}$ by adding suitable volume of Britton Robinson buffer and was allowed to equilibrate for $60 \mathrm{~min}$. Then it was filtered and the filtrate was collected in a $100 \mathrm{~mL}$ volumetric flask and diluted up to mark. Desorption of the adsorbed $\mathrm{Cu}$ (II) was carried out with $10 \mathrm{~mL}$ mixture of nitric acid and hydrochloric acid $(0.5: 4 \mathrm{M})$. The residual metal ions concentration in the filtrates was determined using flame atomic absorption spectrophotometer (FAAS)

Adsorption capacity $\left(\mathrm{q}_{\mathrm{e}}\right)$ of $\mathrm{Cu}(\mathrm{II})$ and percent adsorption was calculated according to the Equation 1 and 2:

$q_{e}=\left[\frac{C_{i}-C_{f}}{m}\right] V$

$\%$ adsorption $=\left[\frac{C_{i}-C_{f}}{C_{i}}\right] \times 100$

In Equation 1 and $2 \mathrm{q}_{\mathrm{e}}$ is the amount of $\mathrm{Cu}$ (II) adsorbed on the adsorbent $\left(\mathrm{mg} \mathrm{g}^{-1}\right), \mathrm{C}_{\mathrm{i}}$ and $\mathrm{C}_{\mathrm{f}}$ represent the initial and equilibrium concentrations of $\mathrm{Cu}(\mathrm{II})$ in $\mu \mathrm{g} \mathrm{mL}^{-1}$, respectively; $\mathrm{V}$ is the volume of $\mathrm{Cu}(\mathrm{II})$ solution $(\mathrm{mL})$ and $\mathrm{m}$ is the amount of adsorbent $(\mathrm{g})$.

RESULTS AND DISCUSSION

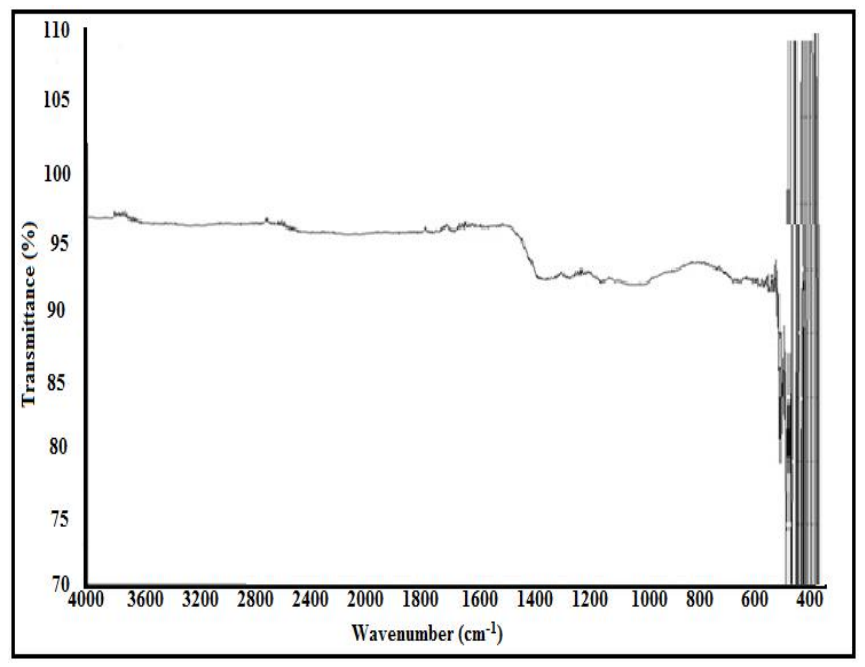

Figure 2. FTIR spectrum of unmodified Amberlite IR-120. 
Characterization of simple and chelated IR- $\alpha N \beta N$ and IR- $8 H Q$

In order to confirm the chelation of Amberlite IR-120, various characterization studies using FTIR, SEM and TGA were conducted. The FTIR spectra of simple and chelated Amberlite were recorded and are shown in Figure 2 and 3, respectively. On comparing the spectra, it was clear that in case of chelated Amberlite IR-120, new IR bands have appeared. These bands are at $1526 \mathrm{~cm}^{-1}$ for $v(\mathrm{~N}=\mathrm{O}), 1348 \mathrm{~cm}^{-1}$ for $v(\mathrm{~N}-\mathrm{H})$ and $\delta(\mathrm{N}-\mathrm{H}), 1626$ and $1383 \mathrm{~cm}^{-1} v(\mathrm{C}=\mathrm{O})$ and 1540 $\mathrm{cm}^{-1}$ for $\mathrm{N}=\mathrm{N}$ group [17]. Thus FTIR analysis indicated the successful chelation of Amberlite IR-120.

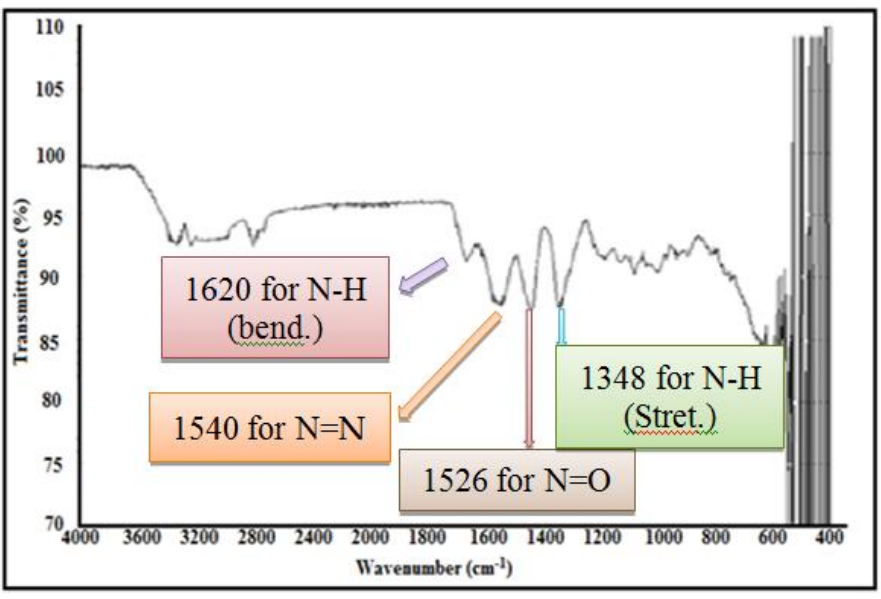

Figure 3. FTIR spectrum of modified Amberlite IR-120.

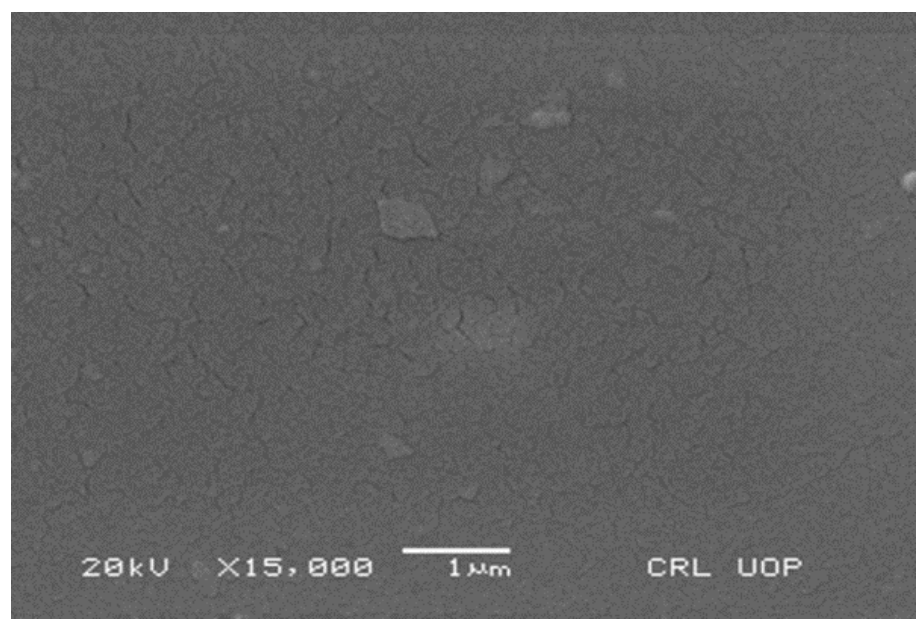

Figure 4. SEM of IR-120. 


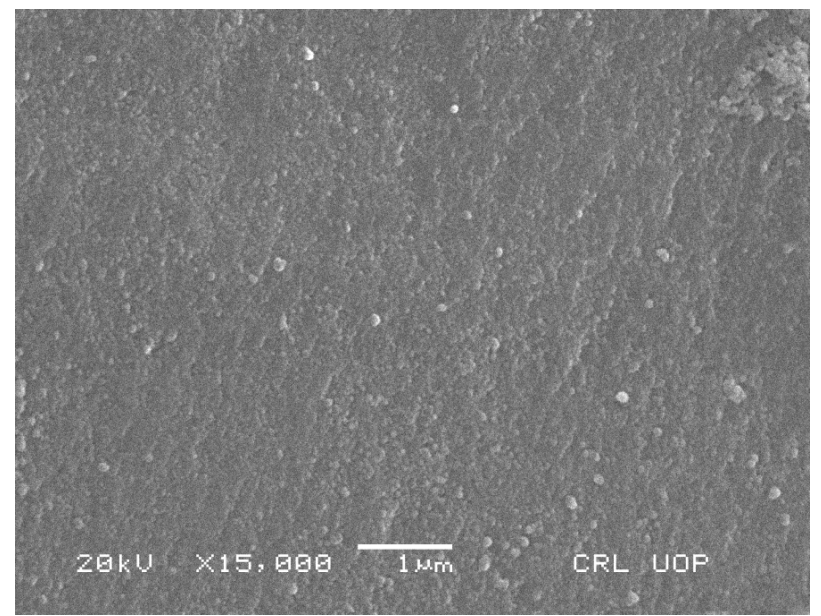

Figure 4a. SEM of IR- $\alpha \mathrm{N} \beta \mathrm{N}$.

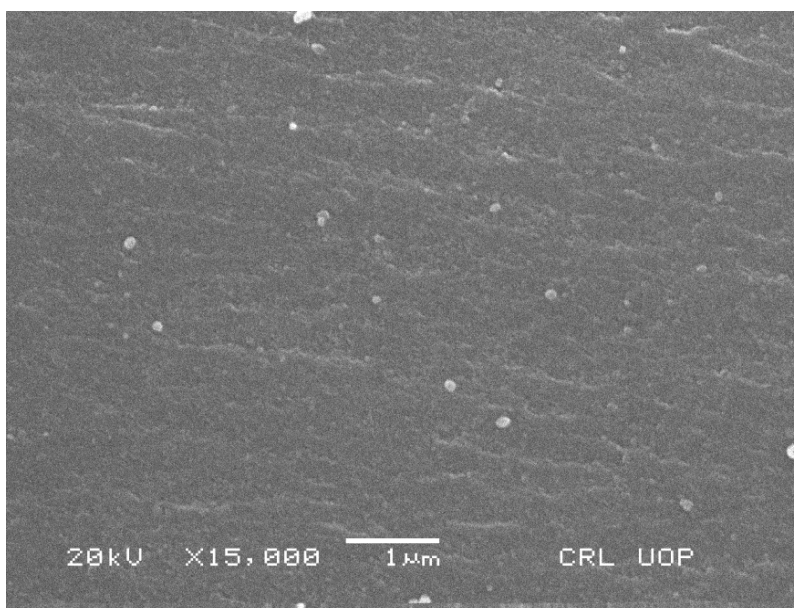

Figure $4 b$. SEM of IR-8HQ.

The surface morphology of simple and chelated Amberlite IR-120 was investigated by SEM at $15000 \mathrm{X}$ magnification. SEM images are shown in Figure 4, $4 \mathrm{a}$ and $4 \mathrm{~b}$. On comparing these images, it can be seen that the surface of Amberlite IR-120 has been modified and has become smoother after chelation with $\alpha$-nitroso $\beta$-naphthol and 8-hydroxy quinolone indicating the successful chelation.

The thermal stability of simple and chelated Amberlite IR-120 was investigated using TGA and is shown in Figure 5. The TGA curve of IR-120 showed two step mass losses up to $400{ }^{\circ} \mathrm{C}$. In the first step the mass loss was $18 \%$ at $310{ }^{\circ} \mathrm{C}$ which may be due to the loss of adsorbed water. In the second step the mass loss was $52 \%$ with greater rate at $410{ }^{\circ} \mathrm{C}$. In case of IR$\alpha \mathrm{N} \beta \mathrm{N}$, the TGA curve showed two step mass losses. In the first step the mass loss was $20 \%$ at 
$300{ }^{\circ} \mathrm{C}$ and in the second step at $360{ }^{\circ} \mathrm{C}$, the mass loss was $60 \%$. Similarly the TGA curve of IR-8HQ showed two step mass losses. In the first step the mass loss was $20 \%$ at $380{ }^{\circ} \mathrm{C}$ and the mass loss in the second step was $40 \%$ at $450{ }^{\circ} \mathrm{C}$. The TGA study shows that skeletal structure of IR-8HQ is strongly linked as compared to IR-120 or IR- $\alpha$ N $\beta N$.

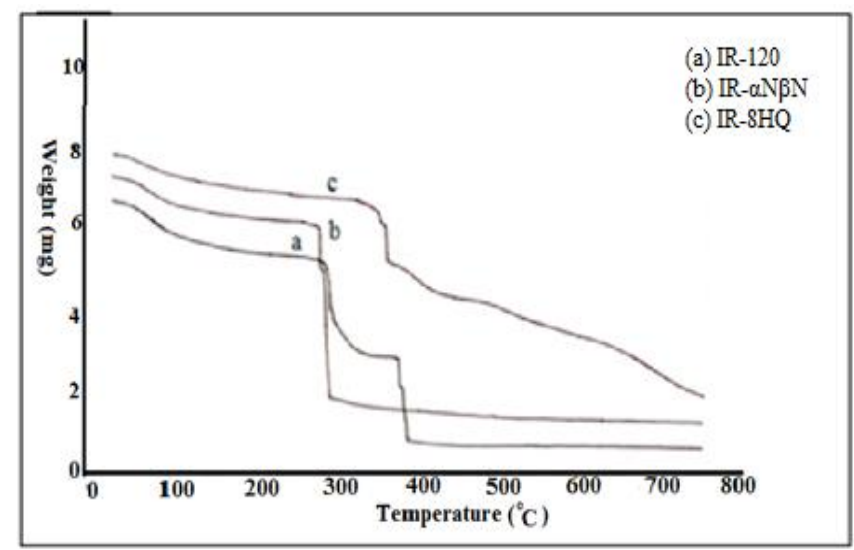

Figure 5. TGA of IR-120 (a), IR- $\alpha \mathrm{N} \beta \mathrm{N}$ (b) and IR-8HQ (c).

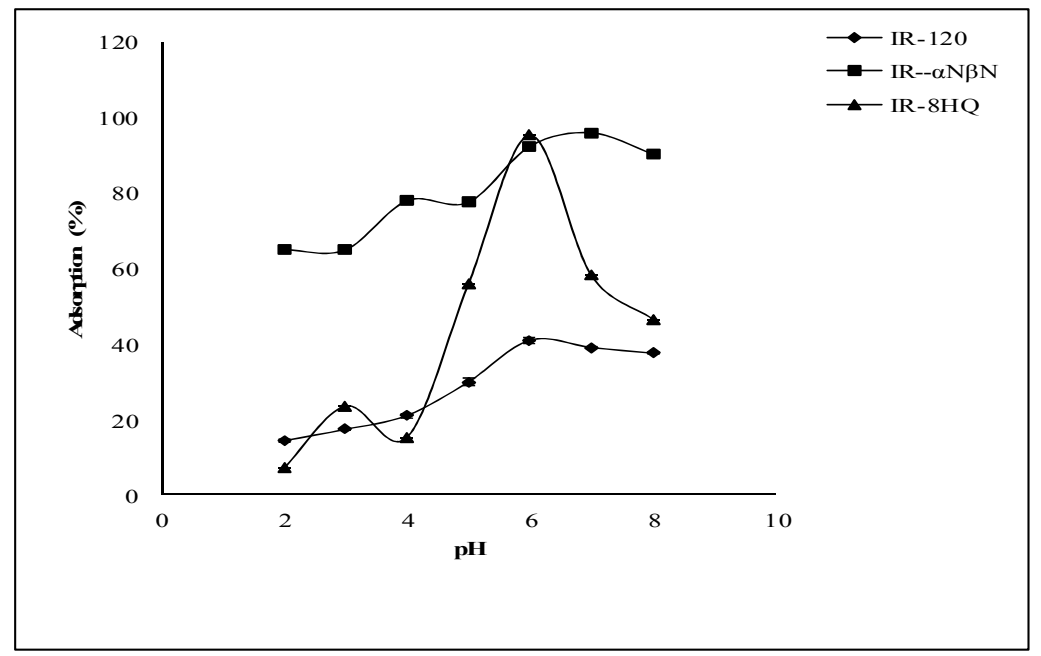

Figure 6. Effect of $\mathrm{pH}$ on $\%$ adsorption of $\mathrm{Cu}(\mathrm{II})$ from aqueous solution using IR-120, IR- $\alpha \mathrm{N} \beta \mathrm{N}$ and IR-8HQ.

\section{Effect of $p H$}

The solution $\mathrm{pH}$ is an important factor which affects the adsorption phenomenon. In order to see the effect of $\mathrm{pH}$ on adsorption of $\mathrm{Cu}(\mathrm{II})$ on these three adsorbents, $\mathrm{pH}$ of the solution was varied from 2.0 to 8.0 using Britton Robinson buffer and the results are shown in Figure 6. The 
adsorption process strictly depends upon solution $\mathrm{pH}$. It can be seen from the figure that maximum adsorption, $41 \%$ and $95 \%$ was observed at $\mathrm{pH} 6$ for IR-120 and IR-8HQ, respectively while in case of IR- $\alpha \mathrm{N} \beta \mathrm{N}$ maximum adsorption (96\%) was observed at $\mathrm{pH} 7$. At lower $\mathrm{pH}$, adsorption was less which may be due to competition between $\mathrm{H}^{+}$and the metal ion for the binding/exchange sites. The adsorption decreased at higher $\mathrm{pH}$ owing to the formation of hydroxide of the metal ions.

\section{Effect of contact time}

Contact time is another important parameter in adsorption process; therefore, the effect of contact time on adsorption behavior of $\mathrm{Cu}$ (II) was investigated in the range of 5 to $70 \mathrm{~min}$ and the results are shown in Figure 7. Generally, adsorption increases with increase in contact time and the same results were also observed with adsorption of $\mathrm{Cu}$ (II). This may be due to the availability of adsorption sites on adsorbent for the target metal ions. As the adsorption process continues, the adsorption sites become occupied and the adsorption process becomes slow. The adsorption of $\mathrm{Cu}(\mathrm{II})$ increased from $17.4 \%$ to $41.0 \%$ in $60 \mathrm{~min}$ for IR-120 and for IR-8HQ, adsorption increased from $38.5 \%$ to $95.3 \%$. In case of IR- $\alpha \mathrm{N} \beta \mathrm{N}$, the rate of $\mathrm{Cu}(\mathrm{II})$ adsorption was quite fast as compared to other two adsorbents and adsorption reached to $97.8 \%$ in first 10 min which indicate that the chelation of $\mathrm{Cu}(\mathrm{II})$ with IR- $\alpha \mathrm{N} \beta \mathrm{N}$ is faster as compared to IR- $8 \mathrm{HQ}$.

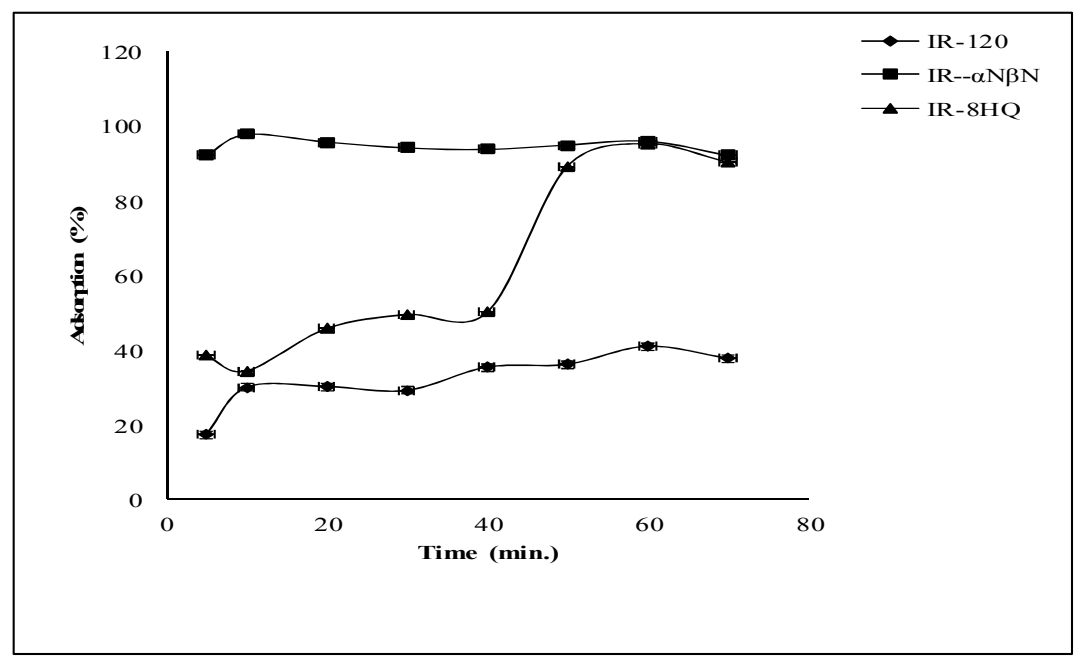

Figure 7. Effect of contact time on \% adsorption of $\mathrm{Cu}$ (II) from aqueous solution using IR-120, IR- $\alpha \mathrm{N} \beta \mathrm{N}$ and IR- $8 \mathrm{HQ}$.

\section{Adsorption kinetics}

The adsorption kinetic data of $\mathrm{Cu}$ (II) were fitted in four common kinetic models like pseudo first order, pseudo second order, intraparticle diffusion and Elovich equations. The model for pseudo first order is expressed by Equation 3:

$\log \left(q_{e}-q_{t}\right)=\log q_{e}-\frac{K_{1} t}{2.303}$ 
where $\mathrm{q}_{\mathrm{e}}$ is the amount of metal ion adsorbed $\left(\mathrm{mg} \mathrm{g}^{-1}\right)$ at equilibrium, $\mathrm{q}_{\mathrm{t}}$ is the amount of metal ions adsorbed $\left(\mathrm{mg} \mathrm{g}^{-1}\right)$ at any given time $(\mathrm{min})$ and $\mathrm{K}_{1}$ is the pseudo first order reaction rate constant for adsorption $\left(\mathrm{min}^{-1}\right)$. The model for pseudo second order is expressed with the help of Equation 4:

$\frac{t}{q_{t}}=\frac{t}{q_{e}}+\frac{1}{K_{2} q_{e}^{2}}$

where $\mathrm{q}_{\mathrm{e}}$ is the amount of metal ion adsorbed $\left(\mathrm{mg} \mathrm{g}^{-1}\right)$ at equilibrium, $\mathrm{q}_{\mathrm{t}}$ is the amount of metal ions adsorbed $\left(\mathrm{mg} \mathrm{g}^{-1}\right)$ at any given time $(\mathrm{min})$ and $\mathrm{K}_{2}$ is the pseudo second order reaction rate constant for adsorption $\left(\mathrm{g} \mathrm{mg}^{-1} \mathrm{~min}^{-1}\right)$.

The constant values of first order kinetics $\mathrm{K}_{1}, \mathrm{q}_{\mathrm{e}}, \mathrm{R}^{2}$ and the second order kinetics $\mathrm{K}_{2}, \mathrm{q}_{\mathrm{e}}$ and $\mathrm{R}^{2}$ were calculated from the slope and intercept of linear line of each model respectively and are given in Table 1. It was observed that not only the correlation coefficient values of the pseudo second order model are higher than that of first order model but the $\mathrm{q}_{\mathrm{e}}$ values of the second order are closer to the experimental $\mathrm{q}_{\mathrm{e}}$ values. This suggests that the adsorption might be controlled by pseudo second order model.

Table 1. Kinetic parameters of $\mathrm{Cu}(\mathrm{II})$ adsorption using IR-120, IR- $\alpha \mathrm{N} \beta \mathrm{N}$ and IR-8HQ.

\begin{tabular}{|c|c|c|c|c|c|c|c|c|c|c|c|c|c|}
\hline \multirow[b]{2}{*}{ Adsorbent } & \multirow{2}{*}{$\begin{array}{c}\mathrm{q}_{\mathrm{e}} \\
(\mathrm{mg} \\
\left.\mathrm{g}^{-1}\right) \\
(\exp .)\end{array}$} & \multicolumn{3}{|c|}{$\begin{array}{l}\text { Pseudo first order } \\
\text { kinetic model }\end{array}$} & \multicolumn{3}{|c|}{$\begin{array}{l}\text { Pseudo second order } \\
\text { kinetic mode }\end{array}$} & \multicolumn{3}{|c|}{$\begin{array}{c}\text { Intraparticle } \\
\text { diffusion model }\end{array}$} & \multicolumn{3}{|c|}{ Elovich model } \\
\hline & & $\begin{array}{c}\mathrm{K}_{1} \\
\left(\mathrm{~min}^{-1}\right)\end{array}$ & \begin{tabular}{|c|}
$\mathrm{q}_{\mathrm{e}}$ \\
$(\mathrm{mg}$ \\
$\left.\mathrm{g}^{-1}\right)$ \\
\end{tabular} & $\mathrm{R}^{2}$ & $\begin{array}{c}\mathrm{K}_{2} \\
\left(\mathrm{~g} \mathrm{mg}^{-1}\right. \\
\left.\min ^{-1}\right)\end{array}$ & $\begin{array}{c}\mathrm{q}_{\mathrm{e}} \\
(\mathrm{mg} \\
\left.\mathrm{g}^{-1}\right)\end{array}$ & $\mathrm{R}^{2}$ & $\begin{array}{c}\mathrm{K}_{\text {int }} \\
\left(\mathrm{mg} \mathrm{g}^{-1}\right. \\
\left.\min ^{1 / 2}\right)\end{array}$ & $\mathrm{C}$ & $\mathrm{R}^{2}$ & $\begin{array}{c}\alpha \\
\left(\mathrm{mg} \mathrm{g}^{-1}\right. \\
\left.\min ^{-1}\right)\end{array}$ & $\begin{array}{c}\beta \\
(\mathrm{g} \\
\left.\mathrm{mg}^{-1}\right)\end{array}$ & $\mathrm{R}^{2}$ \\
\hline IR-120 & 1.14 & 0.020 & 0.616 & 0.809 & 0.072 & 1.21 & 0.959 & 0.091 & 0.323 & 0.878 & 0.398 & 4.69 & 0.866 \\
\hline IR- $\alpha \mathrm{N} \beta \mathrm{N}$ & 2.76 & 0.029 & 0.456 & 0.970 & 0.200 & 2.79 & 0.999 & 0.066 & 2.20 & 0.968 & $7.51 \mathrm{E}+4$ & 6.35 & 0.981 \\
\hline IR-8HQ & 2.45 & 0.038 & 2.325 & 0.826 & 0.012 & 3.20 & 0.885 & 0.276 & 0.123 & 0.938 & $\begin{array}{ll}0.349 \\
\end{array}$ & 1.62 & 0.840 \\
\hline
\end{tabular}

Intraparticle diffusion is a kinetic model which is related to the transfer of adsorbate ions from its aqueous media to the pores of adsorbent. This model is generally expressed by the Equation 5:

$q_{t}=K_{\text {int }} t^{1 / 2}+C$

where $\mathrm{C}$ is the intercept and related to the thickness of the boundary layer and $\mathrm{K}_{\mathrm{int}}\left(\mathrm{mg} \mathrm{g}^{-1}\right.$ $\mathrm{min}^{-1 / 2}$ ) is the intraparticle diffusion rate constant. The values of these constants were calculated directly from the intercept and slope of the graph and are given in Table 1. The plot of $q_{t}$ versus $\mathrm{t}^{1 / 2}$ is not passing through the origin which indicates that intraparticle diffusion is not the controlling step during adsorption of $\mathrm{Cu}$ (II) on these three adsorbents and some other mechanisms are involved.

The Elovich kinetic equation is used to describe the kinetics of chemisorption on heterogeneous surfaces and is given by Equation 6:

$q_{t}=\frac{1}{\beta} \ln (\alpha \beta)+\frac{1}{\beta} \ln (t)$

where $\mathrm{q}_{\mathrm{t}}$ is the amount of $\mathrm{Cu}(\mathrm{II})$ adsorbed $\left(\mathrm{mg} \mathrm{g}^{-1}\right)$ at time (t), $\alpha$ and $\beta$ are known as the Elovich coefficients, $\alpha$ represents the initial adsorption rate $\left(\mathrm{mg} \mathrm{g}^{-1} \mathrm{~min}^{-1}\right)$ and $\beta$ is related to the extent of surface coverage and activation energy for chemisorption $\left(\mathrm{g} \mathrm{min}^{-1}\right)$, respectively. The Elovich coefficients were calculated from the linear plot of $\mathrm{q}_{\mathrm{t}}$ versus $\ln (\mathrm{t})$. It may be concluded from 
kinetic data that pseudo second order kinetic model is a best choice to describe the experimental data as compared to other models.

\section{Adsorption isotherms}

The isotherm models were used to design the adsorption systems of the $\mathrm{Cu}(\mathrm{II})$. These models provide a relationship between the amount of $\mathrm{Cu}(\mathrm{II})$ adsorbed on the adsorbents and the concentration of $\mathrm{Cu}(\mathrm{II})$ in solution at equilibrium. The two most commonly used isotherms models Freundlich and Langmuir were applied to study the adsorption of $\mathrm{Cu}$ (II) on the three adsorbents. The Freundlich isotherm is used generally for non-ideal adsorption on heterogeneous surfaces and is expressed by Equation 7:

$q_{e}=K_{F} C_{e}^{\frac{1}{n}}$

The linear form of Freundlich equation is given in Equation 8:

$\log q_{e}=\log K_{F}+\frac{1}{n} \log C_{e}$

where $\mathrm{K}_{\mathrm{F}}$ is the Freundlich adsorption isotherm constant $\left(\mathrm{mg} \mathrm{g}^{-1}\right), 1 / \mathrm{n}\left(\mathrm{g} \mathrm{L}^{-1}\right)$ and is a measure of the adsorption intensity or the heterogeneity factor whereas $\mathrm{n}$ is the measure of the deviation from linearity of adsorption. Its value indicates the degree of non-linearity between solution concentration and adsorption as follows: if the value of $n$ is equal to unity, the adsorption is linear; if the value is below unity, the adsorption is chemical and if the value of $n$ is above unity then adsorption is a favorable physical process. $\mathrm{q}_{\mathrm{e}}$ is the amount adsorbed $\left(\mathrm{mg} \mathrm{g}^{-1}\right)$ and $\mathrm{C}_{\mathrm{e}}$ is the equilibrium concentration $\left(\mu \mathrm{g} \mathrm{mL} \mathrm{m}^{-1}\right)$.

The Langmuir isotherm is used for monolayer adsorption on a homogeneous surface and is expressed with the help of Equation 9:

$q_{e}=\frac{K_{L} C_{e}}{1+a_{L} C_{e}}$

In a linear form, it is expressed by Equation 10:

$\frac{C_{e}}{q_{e}}=\frac{1}{K_{L}}+\frac{a_{L} C_{e}}{K_{L}}$

where $C_{e}$ is the equilibrium concentration $\left(\mu \mathrm{g} \mathrm{mL} L^{-1}\right), q_{e}$ is the amount of solute adsorbed per gram of adsorbent, $\mathrm{K}_{\mathrm{L}}$ and $\mathrm{a}_{\mathrm{L}}$ are the Langmuir adsorption isotherm constants and are related to the maximum adsorption capacity $\left(\mathrm{L} \mathrm{g}^{-1}\right)$ and bonding strength $\left(\mathrm{L} \mathrm{mg}^{-1}\right)$, respectively. The theoretical monolayer adsorption capacity is $\mathrm{Q}_{\mathrm{o}}$ and is numerically equal to $\mathrm{K}_{\mathrm{L}} \mathrm{a}_{\mathrm{L}}{ }^{-1}$.

From the linear form of these isotherm models for $\mathrm{Cu}(\mathrm{II})$ adsorption on the three adsorbents, the constant parameters of these isotherms were calculated from the slope and intercept of the linear form of these equations and are given in Table 2. The $\mathrm{n}$ values are higher than unity, suggesting that adsorption of $\mathrm{Cu}(\mathrm{II})$ on the three adsorbents is a favorable physical process. Maximum adsorption capacities of IR-120, IR- $\alpha \mathrm{N} \beta \mathrm{N}$ and IR-8HQ were calculated from the linear form of Langmuir isotherm and were found to be $60.28,73.89$ and $71.50 \mathrm{mg} \mathrm{g}^{-1}$, respectively. It can be seen that IR- $\alpha \mathrm{N} \beta \mathrm{N}$ has maximum adsorption capacity as compared to the other two adsorbents. It may be concluded from these results that the adsorption data of $\mathrm{Cu}(\mathrm{II})$ on these three adsorbents were fitted into Langmuir isotherm model with high correlation coefficient $\left(\mathrm{R}^{2}>0.99\right)$. 
Table 2. Freundlich and Langmuir isotherm constants for the adsorption of $\mathrm{Cu}(\mathrm{II})$ using IR-120, IR- $\alpha \mathrm{N} \beta \mathrm{N}$ and IR-8HQ.

\begin{tabular}{|l|c|c|c|c|c|c|c|c|}
\hline \multirow{3}{*}{ Adsorbent } & \multicolumn{4}{|c|}{ Freundlich model } & \multicolumn{4}{c|}{ Langmuir model } \\
\cline { 2 - 10 } & $\begin{array}{c}\mathrm{K}_{\mathrm{F}} \\
\left(\mathrm{mg} \mathrm{g}^{-1}\right)\end{array}$ & $\mathrm{n}$ & $1 / \mathrm{n}$ & $\mathrm{R}^{2}$ & $\begin{array}{c}\mathrm{a}_{\mathrm{L}} \\
\left(\mathrm{L} \mathrm{mg}^{-1}\right)\end{array}$ & $\begin{array}{c}\mathrm{K}_{\mathrm{L}} \\
\left(\mathrm{Lg}^{-1}\right)\end{array}$ & $\begin{array}{c}\mathrm{Q}_{\mathrm{o}} \\
\left(\mathrm{mg} \mathrm{g}^{-1}\right)\end{array}$ & $\mathrm{R}^{2}$ \\
\hline IR-120 & 0.220 & 4.37 & 0.299 & 1.000 & 3.77 & 227 & 60.3 & 0.993 \\
\hline IR- $\alpha \mathrm{N} \beta \mathrm{N}$ & 0.150 & 5.24 & 0.190 & 0.996 & 2.02 & 149 & 73.9 & 0.992 \\
\hline IR-8HQ & 0.091 & 8.73 & 0.114 & 0.867 & 6.08 & 435 & 71.5 & 0.999 \\
\hline
\end{tabular}

Selectivity study

The selectivity study is very important because foreign ions if present along with the target metal ion may form complexes with the chelated adsorbent thus affecting the adsorption of target metal ion. Therefore, the selectivity of the simple and chelated adsorbents was evaluated by studying the effect of selected foreign ions in the range of 50 to $500 \mu \mathrm{g}$ under optimum conditions on adsorption capacity of the adsorbents for the target metal ion (Figure 8-10). It can be seen from Figure 9 that for IR-120, foreign ions are affecting the adsorption capacity of the resin whereas by chelation this interference can be minimized. In case of IR-120 the effect of interfering ions is minimal at lower concentration of foreign ions whereas it increases with increase in the amount of foreign ions. \% adsorption of $\mathrm{Cu}(\mathrm{II})$ decreased up to 49, 50, 54, 44, 22, 49, 43, 51 and 49 in the presence of $500 \mu \mathrm{g}$ of $\mathrm{K}(\mathrm{I}), \mathrm{Na}(\mathrm{I}), \mathrm{Mg}(\mathrm{II}), \mathrm{Ca}(\mathrm{II}), \mathrm{Cd}(\mathrm{II}), \mathrm{Co}(\mathrm{II})$, $\mathrm{Zn}(\mathrm{II}), \mathrm{Ni}(\mathrm{II})$ and $\mathrm{Fe}(\mathrm{III})$, respectively. It can be seen from Figure 10 and 11 that adsorption capacity of IR- $\alpha \mathrm{N} \beta \mathrm{N}$ and IR-8HQ was not affected by foreign ions at low concentration of these ions. With increase in concentration of foreign ions a slight decrease in the adsorption capacity was observed in case of IR- $\alpha \mathrm{N} \beta \mathrm{N}$ while no effect or a very small decrease in adsorption capacity was observed for IR-8HQ. At very high concentration only $\mathrm{Fe}(\mathrm{III}), \mathrm{Ni}(\mathrm{II})$ and $\mathrm{Ca}(\mathrm{II})$ posed serious interference effect. In terms of \% adsorption of $\mathrm{Cu}(\mathrm{II})$, it decreased up to 57,59 , $84,71,65,69,54,70$ and 69 in the presence of $500 \mu \mathrm{g}$ of $\mathrm{K}(\mathrm{I}), \mathrm{Na}(\mathrm{I}), \mathrm{Mg}(\mathrm{II}), \mathrm{Ca}(\mathrm{II}), \mathrm{Cd}(\mathrm{II})$, $\mathrm{Co}(\mathrm{II}), \mathrm{Zn}(\mathrm{II}), \mathrm{Ni}(\mathrm{II})$ and $\mathrm{Fe}(\mathrm{III})$ respectively in case of IR- $\alpha \mathrm{N} \beta \mathrm{N}$. Whereas in case of IR-8HQ, $\%$ adsorption of $\mathrm{Cu}(\mathrm{II})$ decreased up to $89,88,89,83,85,89,91,79$ and 49 in the presence of $500 \mu \mathrm{g}$ of $\mathrm{K}(\mathrm{I}), \mathrm{Na}(\mathrm{I}), \mathrm{Mg}(\mathrm{II}), \mathrm{Ca}(\mathrm{II}), \mathrm{Cd}(\mathrm{II}), \mathrm{Co}(\mathrm{II}), \mathrm{Zn}(\mathrm{II}), \mathrm{Ni}(\mathrm{II})$ and $\mathrm{Fe}(\mathrm{III})$, respectively.

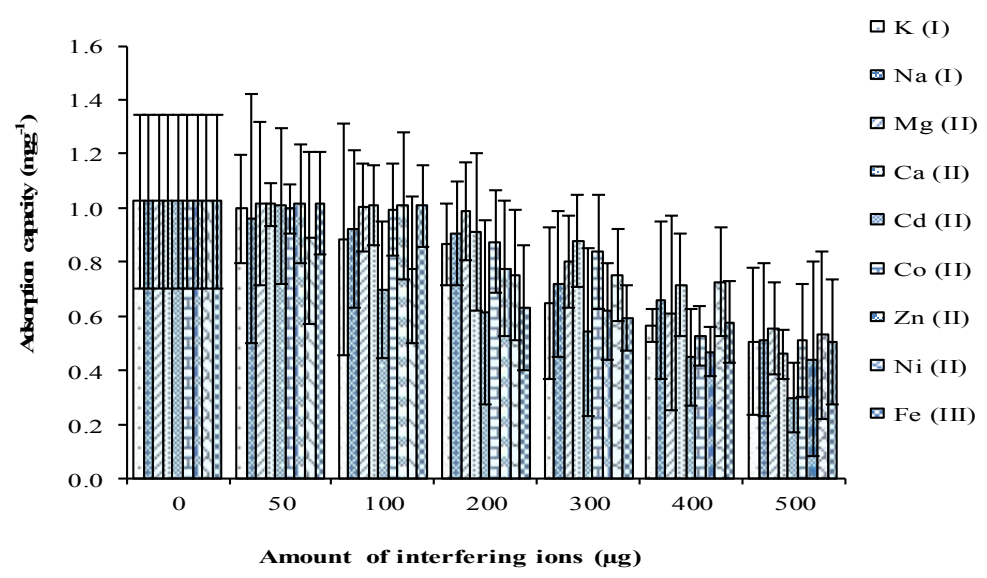

Figure 8. Effect of interfering ions on sorption capacity of $\mathrm{Cu}$ (II) using IR-120.

Bull. Chem. Soc. Ethiop. 2016, 30(1) 


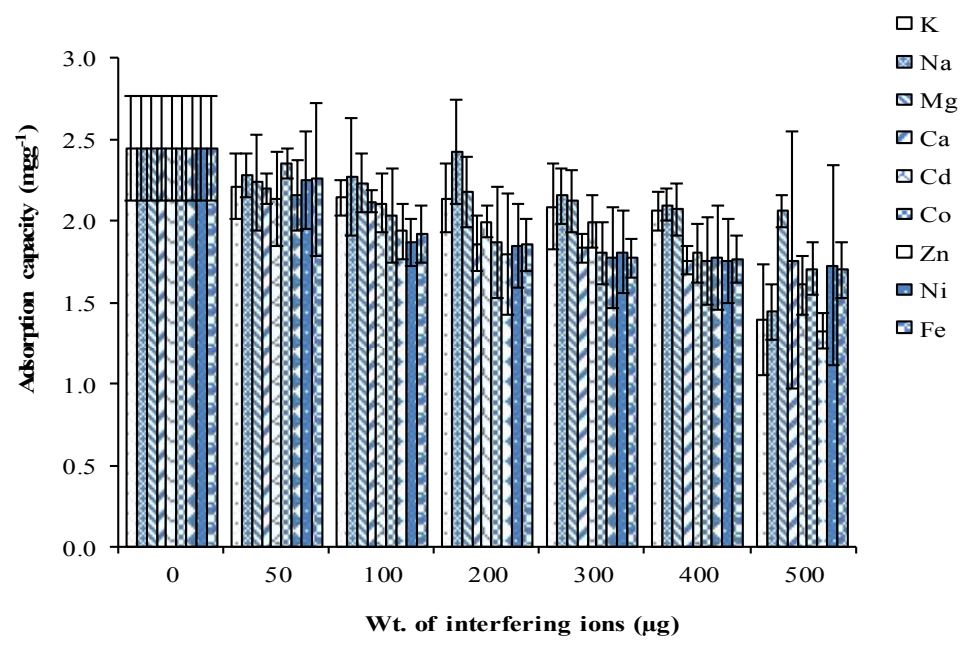

Figure 9. Effect of interfering ions on sorption capacity of $\mathrm{Cu}$ (II) using IR- $\alpha \mathrm{N} \beta \mathrm{N}$.

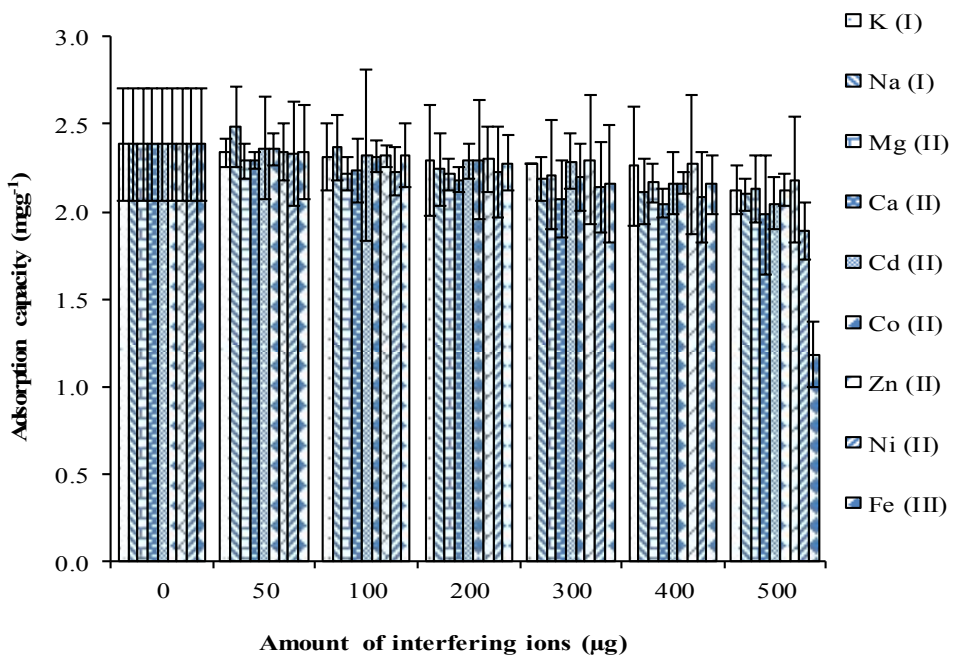

Figure 10. Effect of interfering ions on sorption capacity of $\mathrm{Cu}$ (II) using IR-8HQ.

\section{Desorption studies}

Desorption of the adsorbed metal ions is very important not only for preconcentration and subsequent determination of metal ion at trace level but also for the reuse of the adsorbents. For this purpose, various concentration of hydrochloric acid (0.4-5 M) and nitric acid (0.3-1.2 M) were tried and the residual concentration of $\mathrm{Cu}(\mathrm{II})$ was determined by FAAS. It can be seen from the Table 3 that desorption with $\mathrm{HNO}_{3}$ and $\mathrm{HCl}$ was ineffective in case of unmodified IR120 and IR- $\alpha \mathrm{N} \beta \mathrm{N}$ while in case of IR-8HQ, $73 \%$ and $82 \%$ of $\mathrm{Cu}(\mathrm{II})$ was recovered with $1.2 \mathrm{M}$ $\mathrm{HNO}_{3}$ and $4 \mathrm{M} \mathrm{HCl}$, respectively. 
In order to completely desorb the adsorbed $\mathrm{Cu}(\mathrm{II})$, a mixture of $\mathrm{HCl}$ and $\mathrm{HNO}_{3}$ was also tried in different ratios. The results are shown in Table 4. It can be seen from the table that maximum desorption (86\%) was achieved with a mixture of $4 \mathrm{M} \mathrm{HCl}$ and $0.5 \mathrm{M} \mathrm{HNO}_{3}(3: 2)$ from $\mathrm{Cu}(\mathrm{II})$ loaded IR-8HQ. This indicates that for preconcentration and for the purpose of determination of $\mathrm{Cu}(\mathrm{II})$ at trace level, IR-8HQ is the best option.

Table 3. The effect of various eluents on $\%$ desorption of $\mathrm{Cu}(\mathrm{II})$ from IR-120, IR- $\alpha \mathrm{N} \beta \mathrm{N}$ and IR-8HQ.

\begin{tabular}{|c|c|c|c|}
\hline \multirow{2}{*}{ Eluents } & \multicolumn{3}{|c|}{ Desorption (\%) } \\
\cline { 2 - 4 } & IR- 120 & IR- $\alpha$ N $\beta \mathrm{N}$ & IR- 8HQ \\
\hline $0.3 \mathrm{M} \mathrm{HNO}_{3}$ & $29.5 \pm 0.07$ & $7.12 \pm 0.04$ & $41.9 \pm 0.01$ \\
\hline $0.5 \mathrm{M} \mathrm{HNO}_{3}$ & $16.9 \pm 0.04$ & $23.2 \pm 0.02$ & $74.9 \pm 0.04$ \\
\hline $0.7 \mathrm{M} \mathrm{HNO}_{3}$ & $16.0 \pm 0.06$ & $10.8 \pm 0.09$ & $42.5 \pm 0.02$ \\
\hline $0.9 \mathrm{M} \mathrm{HNO}_{3}$ & $25.0 \pm 0.08$ & $10.2 \pm 0.02$ & $47.6 \pm 0.03$ \\
\hline $1.0 \mathrm{M} \mathrm{HNO}_{3}$ & $11.8 \pm 0.02$ & $13.0 \pm 0.02$ & $66.5 \pm 0.05$ \\
\hline $1.2 \mathrm{M} \mathrm{HNO} 3$ & $19.5 \pm 0.02$ & $19.7 \pm 0.04$ & $73.2 \pm 0.05$ \\
\hline $0.4 \mathrm{M} \mathrm{HCl}$ & $65.3 \pm 0.09$ & $10.3 \pm 0.04$ & $53.8 \pm 0.01$ \\
\hline $0.6 \mathrm{M} \mathrm{HCl}$ & $57.0 \pm 0.01$ & $15.7 \pm 0.02$ & $72.8 \pm 0.02$ \\
\hline $0.8 \mathrm{M} \mathrm{HCl}$ & $20.4 \pm 0.02$ & $23.0 \pm 0.04$ & $73.5 \pm 0.02$ \\
\hline $1.0 \mathrm{M} \mathrm{HCl}$ & $3.41 \pm 0.026$ & $21.9 \pm 0.03$ & $75.0 \pm 0.02$ \\
\hline $2.0 \mathrm{M} \mathrm{HCl}$ & $56.4 \pm 0.02$ & $14.6 \pm 0.09$ & $73.4 \pm 0.04$ \\
\hline $3.0 \mathrm{M} \mathrm{HCl}$ & $24.5 \pm 2.13$ & $15.5 \pm 0.02$ & $57.0 \pm 0.03$ \\
\hline $4.0 \mathrm{M} \mathrm{HCl}$ & $18.5 \pm 0.04$ & $14.9 \pm 0.09$ & $82.0 \pm 0.05$ \\
\hline $5.0 \mathrm{M} \mathrm{HCl}$ & $4.57 \pm 0.08$ & $21.0 \pm 0.04$ & $22.0 \pm 0.03$ \\
\hline
\end{tabular}

Table 4. Desorption of $\mathrm{Cu}$ (II) with mixture of $\mathrm{HNO}_{3}$ and $\mathrm{HCl}$ from loaded IR-120, IR- $\alpha \mathrm{N} \beta \mathrm{N}$ and IR-8HQ.

\begin{tabular}{|c|c|c|c|c|c|}
\hline \multicolumn{2}{|c|}{ IR-120 } & \multicolumn{2}{c|}{$\mathrm{IR}-\alpha \mathrm{N} \beta \mathrm{N}$} & \multicolumn{2}{c|}{ IR-8HQ } \\
\hline $\begin{array}{c}\mathrm{HNO}_{3}: \mathrm{HCl} \\
(0.3 \mathrm{M}: 0.4 \mathrm{M})\end{array}$ & Desorption (\%) & $\begin{array}{c}\mathrm{HNO}_{3}: \mathrm{HCl} \\
(0.5 \mathrm{M}: 0.8 \mathrm{M})\end{array}$ & Desorption (\%) & $\begin{array}{c}\mathrm{HNO}_{3}: \mathrm{HCl} \\
(0.5 \mathrm{M}: 4 \mathrm{M})\end{array}$ & Desorption (\%) \\
\hline $2: 18$ & $9.43 \pm 0.03$ & $2: 18$ & $44.7 \pm 0.04$ & $2: 18$ & $71.4 \pm 0.02$ \\
\hline $4: 16$ & $13.7 \pm 0.01$ & $4: 16$ & $40.6 \pm 0.14$ & $4: 16$ & $84.5 \pm 0.02$ \\
\hline $6: 14$ & $18.2 \pm 0.15$ & $6: 14$ & $45.7 \pm 0.09$ & $6: 14$ & $66.9 \pm 0.01$ \\
\hline $8: 12$ & $14.3 \pm 0.17$ & $8: 12$ & $45.2 \pm 0.04$ & $8: 12$ & $86.1 \pm 0.06$ \\
\hline $10: 10$ & $56.5 \pm 0.06$ & $10: 10$ & $44.4 \pm 0.15$ & $10: 10$ & $61.0 \pm 0.02$ \\
\hline $12: 8$ & $55.2 \pm 0.02$ & $12: 8$ & $31.7 \pm 0.06$ & $12: 8$ & $48.0 \pm 0.01$ \\
\hline $14: 6$ & $6.04 \pm 0.02$ & $14: 6$ & $40.2 \pm 0.02$ & $14: 6$ & $69.0 \pm 0.03$ \\
\hline $16: 4$ & $5.63 \pm 0.01$ & $16: 4$ & $38.6 \pm 0.02$ & $16: 4$ & $63.4 \pm 0.03$ \\
\hline $18: 2$ & $10.8 \pm 0.02$ & $18: 2$ & $41.2 \pm 0.04$ & $18: 2$ & $39.7 \pm 0.02$ \\
\hline
\end{tabular}

The effects of shaking time on desorption of $\mathrm{Cu}(\mathrm{II})$ from IR-120, IR- $\alpha \mathrm{N} \beta \mathrm{N}$ and IR-8HQ was also investigated in the range of 10 to $70 \mathrm{~min}$. The optimum shaking time for desorption of $\mathrm{Cu}$ (II) from IR-120 was $50 \mathrm{~min}$ and for IR- $\alpha \mathrm{N} \beta \mathrm{N}$ and IR-8HQ was $60 \mathrm{~min}$. This indicated stronger bonding with chelated adsorbents as expected than with the simple one. Further it was observed that maximum extraction of $\mathrm{Cu}(\mathrm{II})$ occurred with IR-8HQ.

\section{Effect of sample volume on adsorption capacity and desorption}

For finding out the effect of sample volume, the total metal concentration $(500 \mu \mathrm{g})$ and the amount of adsorbent $(0.1 \mathrm{~g})$ were kept constant and the sample volume was varied from $50 \mathrm{~mL}$ to $500 \mathrm{~mL}$. It was observed that the adsorption of $\mathrm{Cu}$ (II) decreases with increasing sample volume in case of IR-120 whereas an increase was observed for IR-8HQ and IR- $\alpha \mathrm{N} \beta \mathrm{N}$. A linear 
increase in the adsorption capacity was observed for the IR-8HQ with increase in the sample volume.

Desorption of $\mathrm{Cu}(\mathrm{II})$ was also carried out using different volumes for each adsorbent under optimum condition. It was observed that minimum adsorption take place with increase in sample volume in case of simple Amberlite therefore maximum desorption was achieved with increase in sample volume.

The preconcentration factor was calculated for each adsorbent and is given in Table 5. From the table it can be seen that the maximum preconcentration factor of 50 was obtained for IR$8 \mathrm{HQ}$ with maximum desorption of $\mathrm{Cu}(\mathrm{II})$.

Table 5. Preconcentration factor for $\mathrm{Cu}(\mathrm{II})$ from IR-120, IR- $\alpha \mathrm{N} \beta \mathrm{N}$ and IR-8HQ.

\begin{tabular}{|c|c|c|c|c|c|c|c|}
\hline Initial sample & Final eluent & \multicolumn{3}{|c|}{ Preconcentration factor } & \multicolumn{3}{c|}{ Desorption (\%) } \\
\cline { 3 - 8 } volume $(\mathrm{mL})$ & volume $(\mathrm{mL})$ & IR-120 & IR- $\alpha$ N $\beta$ N & IR-8HQ & IR-120 & IR- $\alpha$ N $\beta N$ & IR-8HQ \\
\hline 50 & 10 & 5 & 5 & 5 & 65.3 & 45.7 & 86.1 \\
\hline 100 & 10 & 10 & 10 & 10 & 100 & 44.8 & 100 \\
\hline 150 & 10 & 15 & 15 & 15 & 100 & 59.8 & 100 \\
\hline 200 & 10 & 20 & 20 & 20 & 100 & 54.3 & 100 \\
\hline 300 & 10 & 35 & 35 & 35 & 100 & 66.5 & 100 \\
\hline 400 & 10 & 40 & 40 & 40 & 100 & 71.7 & 100 \\
\hline 500 & 10 & - & 50 & 50 & 0 & 100 & 100 \\
\hline
\end{tabular}

Reusability of IR-120, IR- $\alpha N \beta N$ and IR- $8 H Q$

Reusability of the simple and chelated resins was studied for $\mathrm{Cu}(\mathrm{II})$ with suitable eluting solvents for three consecutive adsorption desorption cycles. IR-120 and IR- $\alpha \mathrm{N} \beta \mathrm{N}$ cannot be reuse as \% adsorption of $\mathrm{Cu}$ (II) decreases to 0.00 whereas IR-8HQ can be reuse five times with a little decrease in $\%$ adsorption of $\mathrm{Cu}(\mathrm{II})$.

\section{Application/recovery studies of the method}

The simple and chelated resins were used for the determination of $\mathrm{Cu}(\mathrm{II})$ in aqueous samples collected from river Jhelum and from the selected tube well and tap water. The aqueous samples were spiked with known concentration of $\mathrm{Cu}(\mathrm{II})$ and their adsorption and desorption was studied. The results are given in Table 6 . The adsorption of $\mathrm{Cu}(\mathrm{II})$ was $38-42 \%$ for IR-120 and $92-96 \%$ for IR- $\alpha \mathrm{N} \beta \mathrm{N}$ and IR-8HQ. It was observed that IR-8HQ is more efficient as compared to other two adsorbents with recovery of $86 \%$.

Table 6. Real sample application for the preconcentration and determination of $\mathrm{Cu}(\mathrm{II})$ with $\mathrm{IR}-120$, IR$\alpha \mathrm{N} \beta \mathrm{N}$ and IR-8HQ.

\begin{tabular}{|c|c|c|c|c|c|c|c|c|}
\hline \multirow{3}{*}{ Sample } & \multicolumn{8}{|c|}{ Spiked aqueous samples } \\
\hline & \multirow{2}{*}{$\begin{array}{r}\mu \mathrm{g} \mathrm{mL}^{-1} \\
\text { added }\end{array}$} & \multirow{2}{*}{$\begin{array}{l}\mu \mathrm{g} \mathrm{mL}^{-1} \\
\text { found }\end{array}$} & \multicolumn{3}{|c|}{ Adsorption (\%) } & \multicolumn{3}{|c|}{ Desorption (\%) } \\
\hline & & & IR-120 & IR- $\alpha \mathrm{N} \beta \mathrm{N}$ & IR-8HQ & IR-120 & IR- $\alpha \mathrm{N} \beta \mathrm{N}$ & IR-8HQ \\
\hline $\begin{array}{c}\text { River } \\
\text { Jhelum }\end{array}$ & 5 & $5.22 \pm 0.23$ & $41.9 \pm 0.71$ & $95.50 \pm 0.12$ & $94.3 \pm 0.32$ & $56.9 \pm 0.34$ & $44.7 \pm 1.04$ & $85.9 \pm 0.14$ \\
\hline $\begin{array}{l}\text { Tube } \\
\text { well }\end{array}$ & 5 & $5.26 \pm 0.41$ & $38.9 \pm 0.13$ & $96.1 \pm 0.13$ & $95.0 \pm 0.23$ & $46.5 \pm 0.01$ & $40.2 \pm 0.42$ & $86.0 \pm 0.02$ \\
\hline $\begin{array}{c}\text { Tap } \\
\text { water }\end{array}$ & 5 & $4.89 \pm 0.48$ & $40.5 \pm 0.25$ & $92.3 \pm 0.23$ & $93.9 \pm 0.13$ & $50.5 \pm 0.36$ & $41.2 \pm 0.35$ & $86.6 \pm 0.10$ \\
\hline
\end{tabular}


Comparison with other adsorbents

The efficiency of chelated Amberlite IR-120 with 8-hydroxyquinoline for removal of $\mathrm{Cu}$ (II) has been compared with other adsorbents given in literature and this comparison is given in Table 7 . Although direct comparison of adsorption capacity of IR-8HQ adsorbent (present work) with other adsorbents is difficult since different experimental conditions are applied for different adsorbents. However it was found that the adsorption capacity of IR-8HQ is much higher than the other adsorbents already reported. This result indicates that IR-8HQ is one of the good adsorbents for the removal of $\mathrm{Cu}(\mathrm{II})$ from aqueous samples.

Table 7. Comparison of maximum adsorption capacity of different adsorbents for $\mathrm{Cu}(\mathrm{II})$.

\begin{tabular}{|l|c|c|}
\hline Adsorbent & Maximum adsorption capacity $\left(\mathrm{mg} \mathrm{g}^{-1}\right)$ & Reference \\
\hline Cationic resin TP 207 & 68.7 & {$[18]$} \\
\hline CT-8HQ & 52.9 & {$[19]$} \\
\hline PTFE selective resin & 39.84 & {$[20]$} \\
\hline Undaria pinnatafida & 38.82 & {$[21]$} \\
\hline Granular activated carbon & 38 & {$[22]$} \\
\hline Electric furnace slag & 32.68 & {$[23]$} \\
\hline H-ePAN fibre mats & 31.3 & {$[24]$} \\
\hline Chitosan & 16.80 & {$[23]$} \\
\hline Ethylenediamine grafted silica & 16.58 & {$[24]$} \\
\hline Peanut hulls & 10.17 & {$[24]$} \\
\hline Hazelnut husk A.C. & 6.645 & {$[24]$} \\
\hline Kaolinite & 10.8 & {$[25]$} \\
\hline Anatase-type titaniumn & 1.3 & {$[25]$} \\
\hline Phosphate rock & 10.8 & {$[25]$} \\
\hline IR-8HQ & 71.5 & Present work \\
\hline
\end{tabular}

\section{CONCLUSIONS}

Simple and chelated Amberlite IR-120 with $\alpha$-nitroso- $\beta$-naphthol (IR- $\alpha \mathrm{N} \beta \mathrm{N}$ ) and with 8hydroxy quinoline (IR-8HQ) was compared for the removal of $\mathrm{Cu}$ (II) from aqueous solutions in batch systems. Scanning electron microscopy (SEM), thermogravimetric analysis (TGA) and Fourier transform infrared spectroscopy (FTIR) confirmed the successful chelation of adsorbents. Among the three adsorbents used IR-8HQ was found to be the best adsorbent for removal of $\mathrm{Cu}$ (II), preconcentration and in respect of its reusability. It was observed that the adsorption of $\mathrm{Cu}(\mathrm{II})$ was strictly $\mathrm{pH}$ dependent. The adsorption data followed Langmuir isotherm. Pseudo second order kinetic model was found to be the best choice as compared to the other kinetic models investigated for description of the data. For reusability of the adsorbents, desorption studies were conducted and maximum desorption (86\%) was observed with a mixture of $4 \mathrm{M} \mathrm{HCl}$ and $0.5 \mathrm{M} \mathrm{HNO}_{3}$ from IR-8HQ. The method was successfully applied to spiked tap water and real samples.

\section{REFERENCES}

1. Duran, C.; Senturk, H.B.; Elci, L.; Soylak, M.; Tufekci, M. J. Hazard. Mater. 2009, 162, 292.

2. Sharma, R.K.; Pant, P. J. Hazard. Mater. 2009, 163, 295.

3. Zheng, Y.; Xiong, C.; Yao, C.; Ye, F.; Jiang, J.; Zheng X.; Zheng, Q. Water Sci. Technol. 2014, 69, 833.

4. Xiong, C.; Yao, C. Iran. J. Chem. Chem. Eng. 2013, 32, 57. 
5. Jiaa, Q.; Xionga, C.; Chena, X.; Zhoua, S.; Yaoa, C.; Ma, C. Desalin. Water Treat. 2013, 51, 4613.

6. Hokkanen, S.; Repo, E.; Suopajarvi, T.; Liimatainen, H.; Niinimaa, J.; Sillanpaa, M. Cellulose 2014, 21, 1471.

7. Zhang, H.; Xiong, C.; Liu, F.; Zheng, X.; Jiang, J.; Zheng, Q.; Yao, C. Water Sci. Technol. 2014, 69, 2446.

8. Wongkaew, M.; Imyim, A.; Eamchan, P. J. Hazard. Mater. 2008, 154, 739.

9. Rekha, D.; Suvardhan, K.; Kumar, J.D.; Subramanyam, P.; Prasad, P.R.; Lingappa, Y. J. Hazard. Mater. 2007, 146, 131.

10. Venkatesh, G.; Singh, A.K. Talanta 2007, 67, 187.

11. Bulut, V.N.; Gundogdu, A.; Duran, C.; Senturk, H.B.; Soylak, M.; Elci, L.; Tufekci, M. J. Hazard. Mater. 2007, 146, 155.

12. Shabani, A.M.; Dadfarnia, S.; Dehghani, Z. Talanta 2009, 79, 1066.

13. Lameiras, S.; Quintelas, C.; Tavares, T. Biores. Technol. 2008, 99, 801.

14. Xiong, C.; Zheng, C.; Feng, Y.; Yao, C.; Ma, C.; Zheng, X.; Jiang, J. J. Mater. Chem. A 2014, 2, 5379.

15. Abhishek, M.T.; Vinay, V.H.; Ashok, B.K. Arch, Appl. Sci. Res. 2012, 4, 1150.

16. Heyrovsky, J.; Zuman, P. Practical Polarography, Academic Press: New York; 1968; p 163.

17. Wongkaew, M.; Imyim, A.; Eamchan, P. J. Hazard. Mater. 2008, 154. 739.

18. Park, K.H.; Parhi, P.K.; Kang, N.H. Sep. Sci. Technol. 2012, 47, 1531.

19. Barros, F.C.F.; Sousa, F.W.; Cavalcante, R.M.; Carvalho, T.V.; Dias, F.S.; Queiroz, D.C.; Vasconcellos, L.C.G.; Nascimento, R.F. Clean Soil Air Water 2008, 36, 292.

20. Zhao, X.W.; Song, N.Z.; Jia, Q.O.; Zhou, W.H. Ind. Eng. Chem. Res. 2011, 50, 4625.

21. Chen, Z.; Ma, M.; Han, M. J. Hazard. Mater. 2008, 155, 327.

22. Kampalanonwat, P.; Supaphol, P. Ind. Eng. Chem. Res. 2011, 50, 11912.

23. Roy, A.; Bhattacharya, J. Chem. Eng. J. 2012, 493, 211.

24. Imamoglu, M.; Tekir, O. Desalination 2008, 228, 108.

25. Sarioglu, M.; Atay, U.A. Desalination 2005, 181, 303. 